\title{
DISCURSO DO BACHARELANDO HUGO CACCURI
}

O orador oficial do "Centro Acadêmico XI de Agosto" é quem haveria de discorrer sobre a figura do insigne mestre Prof. Manoel de Pacheco Prates, cuja morte a douta Congregação da Faculdade de Direito de São Paulo agora glorifica, através da palavra autorizada do Prof. EnNesto LEME, numa homenagem póstuma, com viva expressão de afeto e reconhecimento.

Em virtude do seu não comparecimento, por motivos alheios á sua vontade, fui designado de improviso para ser então o porta-voz do órgão representativo dos estudantes desta Academia, e para exaltar, com a mais profunda veneração, a memória querida do inesquicivel mestre, no trigésimo dia de aniversário do seu passamento.

Desobrigo-me do honroso dever, que se me impôs, satisfeito com a minha conciência e dando largas ás expansões do sentimento, certo de que encontrarei, na vossa benevolência, o pálio protetor da deficiência da minha palavra. Valha, acima de tudo, a intenção que me anima, de prestar sentido preito a quem tanto, em vida, fez jús pelo coração e pela inteligência.

Ha pouco, no recolhimento sagrado á recordação dos que se foram para a mansão dos justos, quando eu meditava sobre a fragilidade e contigência da nossa vida, veiu-me á lembrança uma página admiravel de Anatole France e na qual o cético do "Jardim de Epicuro" faz ressaltar uma filosofia profunda sobre o destino dos homens. Quando um dos seus personagens de ficção, representado pelo nome de Pirro, perguntava, em busca de um sentido orientador, o que era Vida, Claudio Bernard, como gênio afeito aos mis- 
térios da humanidade, responde que a "Vida é a Morte", glorificando esta como a evocação de uma existência.

Pois bem.

Hoje, no instante em que se comemora solenemente a morte do professor Pacheco Prates, o que se faz é trazer a imaginaçâo a glória de sua vida, cheia de belezas morais acrisoladas nas virtudes de um espirito atreito á luta e de um temperamento que marcou o traço, depois de combate verdadeiro, de uma personalidade incontrastavel.

Esta invocação, sincera da nossa parte, no trigésimo dia de seu trespasse, contraria a atitude dos que medem as afeições pela páuta do tempo, que as arrefece, maneira como Musset cristalizou em verso, quando vaticinou que "quinze dias fazem de uma morte recente, velha noticia"

Felizmente, nós não pertencemos a esta grei!

Para nós, que sempre soubemos respeitar e cultuar a sombra dos que aqui viveram ensinando as sábias lições do Direito, o tempo, isso sim, é a flama que aguça mais a recordação, aviventando, em nossos pensamentos, as figuras dos mestres que, como a de Pacheco Prates, pertencem ás tradições gloriosas desta casa.

Aos olhos dos que se iniciam agora na vida prática, onde se ha mistér concretizar na realidade dos fatos humanos os princípios jurídicos que a teoria forjou, manifestações como esta têm o sortilégio de fazer crer o que vale uma vida devotada aos livros, maximé quando a época material de hoje só se preocupa com exteriorizações e descrê da vitória imarcescivel da idéia e da inteligência. Ninguem mais do que Pacheco Prates foi, a este respeito, batalhador inconcusso a serviço do Direito.

Versado nas questões do Direito Civil, ele não poderia deixar de ser, com brilho invulgar, um exímio romanista e reconhecer que o Direito Romano é a fonte inexaurivel dos ensinamentos jurídicos através dos tempos.

Mas mestre do saber, honrando a cátedra com esclarecida erudição e as tradições da Faculdade de Direito de São 
Paulo, que tanto prezou e tanto amou, Pacheco Prates era tambem mestre de bondade infinita, atencioso no trato afavel para com os seus estudantes e os funcionários desta Academia, trato que lhe grangeou a merecida auréola de simpatia, que todos nós lhe devotamos.

Estou a vê-lo ainda aqui, entre nós, meio curvado sob o pêso anoso do estudo e do sacrificio, com as cans a cobrirem-lhe os cabelos, arrimado ao braço de uma pessôa amiga dirigir-se para a sala de áulas e ministrar do sólio, que tanto elevou, as últimas lições.

$\mathrm{E}$, como que num simbolismo parece-me vêr lá longe, na terra que Bento Gonçalves amou, os braços da cruz do seu jazigo serem os mesmos braços de carne, trêmulos, acenando para nós, para a vida!

Vá ao seu encontro, como si fossem flores esparzidas pelo lêito, onde dorme o derradeiro sono, como prêito de saudade, o coração da juventude da Academia de Direito de São Paulo. 